\title{
MEDITERRANEAN'S CHANGING SALTSCAPES: A STUDY OF THE ABANDONMENT OF SALT-MAKING BUSINESS IN GREECE
}

\section{T. PETANIDOU \\ A. DALAKA}

Received: 05/12/08

Accepted: 18/03/09

\author{
Laboratory of Biogeography and Ecology, \\ University of the Aegean, Department of Geography, \\ University Hill, GR-81100 Mytilene, Greece
}

*to whom all correspondence should be addressed: e-mail: t.petanidou@aegean.gr

\begin{abstract}
Saltscapes are landscapes with a long lasting salt-making activity, thus embedded with a blend of salt-related characteristics that marked them physically, ecologically, economically, and culturally. This study, based on a broad survey, focuses on the changing atlas of saltmaking business and the consequent land use change in Greece within the $20^{\text {th }}$ century.

Like in many Mediterranean countries, salt-making has been an important activity in Greece, not only because salt catered for local and national needs (food condiment and preservative; basic resource in husbandry and industry), but also because it offered significant revenues to the Greek State. Taxed salt has been produced in 28 semi- or entirely-mechanized State saltworks. The remaining less productive salinas operated in clandestine and were numerous: 48 in lagoons and 307 on rocks. Both salina types produced either self-formed salt or were man-managed (primitive, artisanal). This very dense network of salt-making sites, all located along the coastline, was in operation mostly until WW II, thereafter many sites were gradually abandoned. Today only eight saltworks are active in Greece (dormancy $71.4 \%$ ) and, despite their increased potential, the overall saltscape loss in the country is significant. Salinas operating in lagoons suffered a spectacular change (93.4\%) compared to those on rocks $(43.0 \%)$. We discuss the reasons of abandonment, especially the role of "globalization" in heritage loss (ecological, cultural). We compare salinas on islands and the mainland as to typology and values and we propose ways of recuperating these threatened resources by using them as alternative poles for local development mainly through tourism.
\end{abstract}

KEYWORDS: Salt-making atlas; land use change; salinas; saltworks; heritage.

\section{INTRODUCTION}

Salinas, saltworks and saltscapes: definitions, values, awareness

The general term salina describes the site or the installation where salt-making takes place through brine evaporation as a result of a natural or artificial processing (Multhauf, 1978; Bergier, 1982; Lemonnier, 1984; Petanidou, 1997a). In the Mediterranean brine evaporation has been generally assisted by solar irradiance, although there is archaeological evidence that ebullition has been also in use in Prehistoric Times, in some cases until Medieval Times (Escacena-Carrasco and Rodriguez de Zuloaga, 1994; Escacena-Carrasco et al., 1996; Petanidou, 1997a; Rodríguez-Rodríguez, 2000; Valiente-Cánovas et al., 2002).

The term salina has been used repeatedly as a replacement of the term saltworks, therefore giving the impression that there is no clear difference in their meaning (Petanidou 1997a, 2002). A more scrutinizing glance in the literature, however, reveals that saltworks have been mostly related to large-scale salt-making installations, i.e. partly or fully mechanized to huge industrial ones, where salt is gained from brine (sea water, salt spring, brine mined or manufactured by dissolving salt rock) or directly from mining (rock salt). Saltworks limited in surface and run basically by one manually-working person are referred to as salinas. The latter, comparable to the salt gardens of the roman antiquity, are further distinguished in 
primitive (i.e. producing self-formed salt) and artisanal (i.e. related to manual production and craftsmanship) (Bergier, 1982; Lemonnier, 1984; Luengo and Marín, 1994; Petanidou, 1997a, 2000; 2001a; ALAS project, 2002).

Since many centuries the Mediterranean saltworks have been functioning with the system of successive evaporation basins, which has been brought into the Basin probably by Arabs before the $10^{\text {th }}$ century (Petanidou, 1997a). These saltworks can be distinguished today into two basic types: (i) fully mechanized, i.e. huge industrial plants employing continuous crystallization throughout the salt-making period (May - September) and almost no manual work for brine pumping and salt harvesting; and (ii) semi-mechanized, i.e. similar to the previous type in many features and deferring in that they employ considerable manual work as to salt harvest and brine circulation. From the economic viewpoint fully mechanized saltworks are the most profitable due to their high productivity, reduced labor involved, and high chemical quality of the salt produced (relatively pure $\mathrm{NaCl}$ ). Yet, depending positively on their size, all saltwork types constitute invaluable wetlands at national, and very often at the international or world level (Petanidou, 1997d; Walmsley, 2000; Sadoul, 2002).

Salt-making marked intensively the landscape during different times and in many ways:

1. physical (e.g. by creating "salt mountains" - as in Cardona, NE Spain, where mined byproducts were left aside in huge quantities; or by drowning extensive coastal areas - as in the Dutch Frisia in the $15^{\text {th }}$ century, where the catastrophic events resulted from turf extraction that had been used for the ebullition of brine);

2. environmental (e.g. by deforesting former forests used as fuel for the ebullition of brine; this is how Lüneburg heath, in Germany, came about);

3. ecological (e.g. by enhancing the presence of particular halophilous flora and fauna);

4. cultural (e.g. architecture, know-how, folklore, history); and, of course,

5. economic (innumerable cases: Multhauf, 1978; Bergier, 1982; Petanidou, 1997a).

The above blend of aspects brought about particular landscapes that are bound to salt production in an area, thus named saltscapes (Hueso-Kortekaas, 2005). In saltscapes natural and cultural elements are not only mutually related to each other, but they are both conditioned by and depend on salt-making activity. Saltscape studies can be excellent examples of landscape studies, as they may concern not only natural habitats but also the interactions between them.

Depending on their particular characteristics all saltscapes are invaluable for the society, because they encompass a vast span of values including cultural and ecological ones due to their architecture, rare halophytic communities, extraordinary salt-tolerant species, hypersaline wetland loving birds, human inventions and craftsmanship to manage brine, and social life related to salt (Kastritsi-Katharios, 1991; Goutner and Papakostas, 1992; PérezHurtado and Hortas, 1993; Marín and Orlando, 1997; Thibault et al., 1997; Petanidou, 1997a, 2001b; Galinou, 1999; Thompson, 1999; Buron, 1999; Masero and Pérez-Hurtado, 2001; Petanidou, 2001b; 2004; Petanidou and Vayanni, 2002; Sadoul, 2002; Geslin et al., 2002; Masero, 2003; Neves et al., 2005, Evagelopoulos et al., 2009, Lekkas and Korovessis, 2009, Zeno, 2009). However, most of the saltscapes in the Mediterranean, especially those in remote areas, are threatened today and disappearing quickly under the pressure of tourism imposing strong land use changes. This is sustained on the one hand by the loss of salt value due to refrigeration and, on the other, the high-tech industry producing extremely low-cost salt through thermocompression. This technique, mainly suitable to northern Europe, has started to be also applied in some Mediterranean saltworks such as those of Pag, Croatia (Petanidou, personal observation). Yet, due to their declining socio-economic activity, most saltscapes can hardly fight the strong commercial concurrence from the powerful salt-making companies inside and outside the Mediterranean basin. This deterioration process of traditional saltscapes will affect negatively local salt culture and biodiversity, and therefore accelerate further loss of heritage.

All the above imply that saltscapes today need particular attention and conservation care. Such conservation interest has been already manifested at different levels of focus and action, from the local (e.g. Kastritsi-Katharios, 1991; Luengo and Marín, 1994; Petanidou, 1997b; Buron, 1999; Kalafatis et al., 2003) to regional and interregional (Petanidou et al. 
2002a; Neves et al. 2005). In fact, European saltscapes have attained a raising attention the last decades by International Organizations such as UNESCO, INSULA, MedWet, and Ramsar Convention (Marín and Orlando, 1997; Petanidou, 2001b; Petanidou et al., 2002a), by numerous NGOs that are active locally (Hueso-Kortekaas, 2005), by natural scientists and historians (Multhauf, 1978; Malpica-Cuello, 1981, 1991; Adshead, 1992; Quesada and Malpica-Cuello, 1994; Petanidou, 1997a; Sadoul et al., 1998; Buron, 1999; Davis, 2000a,b, 2009; Weller, 2002; Amorim, 2005; Hocquet and Sarrazin, 2006, Crisman et al., 2009), by managers and owners (Korovessis and Lekkas, 2000; Hueso-Kortekaas, 2004; Lekkas and Korovessis, 2006), as well as by local developers and authorities (Marín and Orlando, 1997; Quaranta et al., 2000; Petanidou et al., 2002a; Kalafatis et al., 2003; Neves et al., 2005). This interest is perfectly justified not only because of the values embedded in these saltscapes, but also because saltscapes constitute an important capital to be potentially used as an alternative resource for sustainable local development (Marín and Orlando, 1997; Petanidou and Vayanni, 2002; Petanidou et al., 2002a). Saltscapes, however, remain unknown to the general public, primarily because they are restricted to marginal areas, or because they are quickly shifted to new land uses once they are abandoned (Sadoul et al., 1998).

\section{Study scope}

In this paper we explore the changing geography of saltscapes in the Mediterranean using extensive quantitative data, an effort that has never been undertaken so far. We use Greece as a case study, focusing primarily on the identification of the salt-making sites encountered in the country and exploring the saltscape use changes within the last two centuries, specifically since the formation of the Greek State in 1831. We considered Greece a good choice, first because of its extended coastline (ca. 17,000 km long) available for salt-making; and second because of the broad network of islands, archipelagoes and peninsulas, all isolated and requiring locally produced salt to cater for the needs of their inhabitants. We address questions related to the geographical dimensions and the motives for the changes regarding typology, production potential, size and other physiographic characteristics of the salt-making sites in the country. We hypothesize that the processes of abandonment differ greatly between the mainland and the islands, with the latter suffering a higher abandonment rate than the former. If so, islands are expected to experience a higher rate of heritage loss in terms of craftsmanship and culture, as well as impoverishment of landscape and biodiversity.

\section{METHODOLOGY}

In order to document as completely as possible all salt-making activities, i.e. both typical (systematic salt-making) and atypical, we retrieved information from the following sources: (i) literature review, (ii) structured questionnaires sent all over the country, and (iii) open interviews and research on the spot in areas of particular interest.

\section{Literature review}

Literature review focused primarily on the large State saltworks that have been in operation on the Greek territory. Sources of information included conventional and aerial photos, old maps and encyclopedias, books and other publications, as well as public or private archives. Much of this material has been collected by the senior author since the 1980 s (Petanidou, 1987, 1997a).

\section{Questionnaire survey}

The most difficult part of the research was to pinpoint and document those obscure saltmaking places scattered all over the Greek territory, mostly illegal in the past, and for which no statistical or official data were available. Such information was collected systematically through a structured questionnaire survey carried out all over Greece. Target respondents were knowledgeable residents of places related to salt-making. In particular, the questionnaires were sent to: (i) all prefecture authorities; (ii) all coastal communities (towns, villages); (iii) all coastal and inland areas with place names indicative of salt-making activity. We used all salt- and salina-related place names found in different encyclopedias as well as appearing in the maps of Greece and the list of place names issued by the Geographical Agency of the Greek Army (GYS, 1998). The total number of scrutinized place names and 
localities amounted to 284 including all those literally related to "salina" (alyki, touzla), "salt" (als, alas, alati), "salty" (almyros, armyros), as well as those starting with "al", "ar" and "aspr".

The structured questionnaires were directed to the competent local authorities (e.g. prefectures, municipalities, village councils, etc) and, if possible, to particularly authorized/appointed persons. Each questionnaire included 16 closed, open or multiple choice questions referring to the salina typology (substrate, expanse), productivity, locality, time of operation, methodology employed, and the tools used to harvest salt. The questions also meant to explore other issues (e.g. economy, culture, gastronomy) that are not dealt with in the present paper.

In total 396 questionnaires were sent out to an equal number of coastal municipalities and village councils, as well as to inland prefectures. Sending was done in three phases: to all recipients in July 2000, whereas in January 2001 and August 2001 to those authorities that did not respond in earlier calls. Additional sporadic dispatches and many hundreds of phone calls to potential respondents were made throughout the whole survey. By March 2003, when the survey ended, 263 filled questionnaires were received (i.e. $66.4 \%$ recovery). For those municipalities from which we received no feedback we made sure through telephone calls that their areas were never related to salt-making.

\section{Research on the spot}

In addition to all the above sources we used the experience and information gained on the subject from numerous field trips and research projects carried out since 1980s (Petanidou, 1987; 1989; 1991; 1994; 1997b,c; 2004; Petanidou et al., 1991; 2002a; 2002b; Neves et al., 2005). Many field trips were undertaken within the project ALAS (2002), specifically to the islands (e.g. Dodecanese, Cyclades), S. Peloponnesus, and Kythera. During all these trips we interviewed not less than 150 different persons, all related somehow to local salt-making.

\section{Data analysis}

To facilitate data analysis all information collected was inserted in a spatial database employing Geographic Information Systems (GIS). We used the Eurostat NUTS code system, which has been applied for the management of NATURA 2000 sites network. Maps were produced using ArcMap 8.1 software.

For the geographical analysis (i.e. distribution of salt-making sites all over the country), we did not use pure administrative criteria, but considered also the physical characteristics of the areas (e.g. climatic profile, isolation), so that each geographical area constitutes a homogeneous entity. As a result, salt-making sites were assigned to the following greater geographical areas: N. Greece (comprising Macedonia and Thrace); C. Greece (comprising Epirus, Thessaly, and Sterea Hellas including Evoia); Peloponnesus; Crete (with the surrounding small islands); Dodecanese; Cyclades (including the nearby islands of the Saronic gulf, viz. Hydra, Spetsae and Aegina); N. Aegean Islands (encompassing all the remaining islands of the Aegean, i.e. except Crete, Evoia, the Dodecanese and the Cyclades); and Ionian Islands (including Kythera and Antikythera).

Because detailed annual salt yields were unavailable we used average data, focusing on two major periods: before and after 1960s, a decade that marked the shift from traditional to modern Greece.

Throughout the paper averages are followed by standard error (SE).

\section{RESULTS}

Of the 263 local authorities that responded to our questionnaires (hereafter called "respondents"), 144 were related to salt-making. The total number of salt-producing sites (hereafter also called "facilities") all over the country amounted to 384, of which only 186 continue to be active nowadays. They are illustrated in Maps 1-3 distinguishing state saltworks (28 in number; Map 1), primitive salinas on lagoon substrate (48; Map 2), and primitive salinas on rocky substrate (307; Map 3). Figure 1 shows key values related to the development of the Greek saltworks in the last two centuries, whereas Figure 2 shows the changes that occurred to primitive salinas after the 1960s. Table 1 gives data pointing up the 
abandonment of salt-making facilities in Spain, the only Mediterranean country in which such data are available. Tables 2-3 give some quantitative data exemplifying the dwindling saltmaking activity in Greece.

Table 1. Abandonment of salt-making activities in Spain.

We give the number of the major salt-making facilities in the country (inland salinas, coastal saltworks and salt mines) for three distinct periods since the 1930s

\begin{tabular}{lccc}
\hline & \multicolumn{3}{c}{ Number of salt-making facilities } \\
\cline { 2 - 4 } & $1930-1945^{*}$ & $1995^{\star \star}$ & $2003^{\star \star *}$ \\
\hline inland salinas & 167 & 32 & 24 \\
coastal saltworks & 43 & 24 & 22 \\
salt mines & 12 & 12 & 4 \\
\hline
\end{tabular}

Sources: *Altimir-Bolva (1945); **Instituto Tecnológico Geominero de

España (1997) ; ${ }^{* * *}$ Instituto Geológico y Minero de España (2003)

Table 2. Quantitative data of the salt-making facilities in Greece.

We give total number, overall surface area and production potential of the facilities all over the country. In all peninsula cases we considered the facilities if only located on the half tip (i.e. the peninsulas of Lakonia and Messinia in Peloponnesus and Toroni in Chalkidiki)

\begin{tabular}{lccc}
\hline Type of salt-making facility & $\begin{array}{c}\text { Number of salt-making facilities } \\
\text { operating in the } \\
\text { past }\end{array}$ & active today & \% active \\
\hline In number & & \\
on rocky coast & $\mathbf{3 0 7}$ & $\mathbf{1 7 5}$ & $\mathbf{5 7 . 0}$ \\
on islands & 253 & 161 & 63.6 \\
on islands \& peninsulas & 276 & 163 & 59.1 \\
on mainland (excl. peninsulas) & 31 & 12 & 38.7 \\
on earthy (lagoon) substrate & $\mathbf{4 8}$ & $\mathbf{3}$ & 6.3 \\
on islands & 21 & 0 & 0.0 \\
on islands \& peninsulas & 27 & 0 & 0.0 \\
on mainland (excl. peninsulas) & 21 & 3 & 14.3 \\
inland & $\mathbf{1}$ & $\mathbf{0}$ & $\mathbf{0}$ \\
& & & \\
on rocky coast & $\mathbf{1 1 6 . 7}$ & $\mathbf{4 6 . 5}$ & $\mathbf{3 9 . 8}$ \\
on islands & 65.1 & 35.8 & 55.0 \\
on islands \& peninsulas & 72.7 & 37.1 & 51.0 \\
on mainland (excl. peninsulas) & 44.0 & 9.4 & 21.4 \\
on earthy (lagoon) substrate & $\mathbf{1 0 5 5 . 2}$ & $\mathbf{3 0 . 0}$ & $\mathbf{2 . 8}$ \\
on islands & 928.6 & 0.0 & 0.0 \\
on islands \& peninsulas & 942.1 & 0.0 & 0.0 \\
on mainland (excl. peninsulas) & 113.1 & 30.0 & 26.5 \\
& & & \\
on rocky coast & In salt-making potential (metric tons) & $\mathbf{2 2 7 . 3}$ & $\mathbf{3 8 . 9}$ \\
on islands & $\mathbf{5 8 4 . 0}$ & 213.6 & 60.0 \\
on islands \& peninsulas & 356.0 & 221.1 & 44.1 \\
on mainland (excl. peninsulas) & 501.3 & 6.3 & 7.6 \\
on earthy (lagoon) substrate & 82.8 & $\mathbf{3 . 0}$ & $\mathbf{0 . 2}$ \\
on islands & $\mathbf{1 4 3 8 . 7}$ & 0.0 & 0.0 \\
on islands \& peninsulas & 874.7 & 0.0 & 0.0 \\
on mainland (excl. peninsulas) & 996.2 & 3.0 & 0.7 \\
\hline
\end{tabular}




\section{DISCUSSION}

\section{An overview of the geography of salt-making in Greece}

Salt has been produced all over Greece the last centuries, which is indicative of the plentiful salt-making resources available on the country's long coasts (viz. 383 facilities scattered on the coast, both on the islands and the mainland). Such a distribution indicates that the entire Greek coastline from the south to the north is all endowed with a climate required for salt production: negative water balance, low relative air humidity, and steady winds during the salt-making period (ca. May to September). At the same time, such a dense distribution of salt-making sites is indicative of the absence of large flat expanses that could cover the salt needs of major inland areas.

A second conclusion stemming out from our results is that salt has been produced exclusively on the coast (Maps 1-3). Unlike the Iberian peninsula, and especially Spain having more than 200 inland salinas (Hueso and Neves, 2005; Hueso, personal communication; Table 1), Greece is deprived of such facilities: except from an inland salina that has used brine from a brackish lake (i.e. the lake Pikrolimni in N. Greece, which operated for a very short period during WW II), all the remaining salt-making sites in Greece use seawater as raw material. In all these sites solar irradiance and wind power constitute the main fuel to evaporate water and crystallize salt. The non occurrence of inland salinas in Greece, however, does not

Table 3. Non-typical salt-making facilities in Greece.

We give the remaining \% over the originally existed number of sites, total surface and production potential in different geographical departments (data from 2003)

\begin{tabular}{|c|c|c|c|c|c|c|}
\hline \multirow{3}{*}{ Region } & \multicolumn{6}{|c|}{$\%$ of activity } \\
\hline & \multicolumn{3}{|c|}{ on rocky coast } & \multicolumn{3}{|c|}{ on lagoon substrate } \\
\hline & \# sites & Area & Production & \# sites & Area & Production \\
\hline Crete & 61 & 67 & 57 & 0 & 0 & 0 \\
\hline Dodecanese & 64 & 49 & 69 & 0 & 0 & 0 \\
\hline Cyclades & 62 & 7 & 9 & 0 & 0 & 0 \\
\hline N. Aegean Islands & 61 & 93 & 71 & 0 & 0 & 0 \\
\hline Ionian Islands & 86 & 83 & 99 & 0 & 0 & 0 \\
\hline Peloponnesus & 29 & 38 & 17 & 0 & 0 & 0 \\
\hline C. Greece & 48 & 11 & 26 & 30 & 48 & 29 \\
\hline N. Greece & 0 & 0 & 0 & 0 & 0 & 0 \\
\hline
\end{tabular}

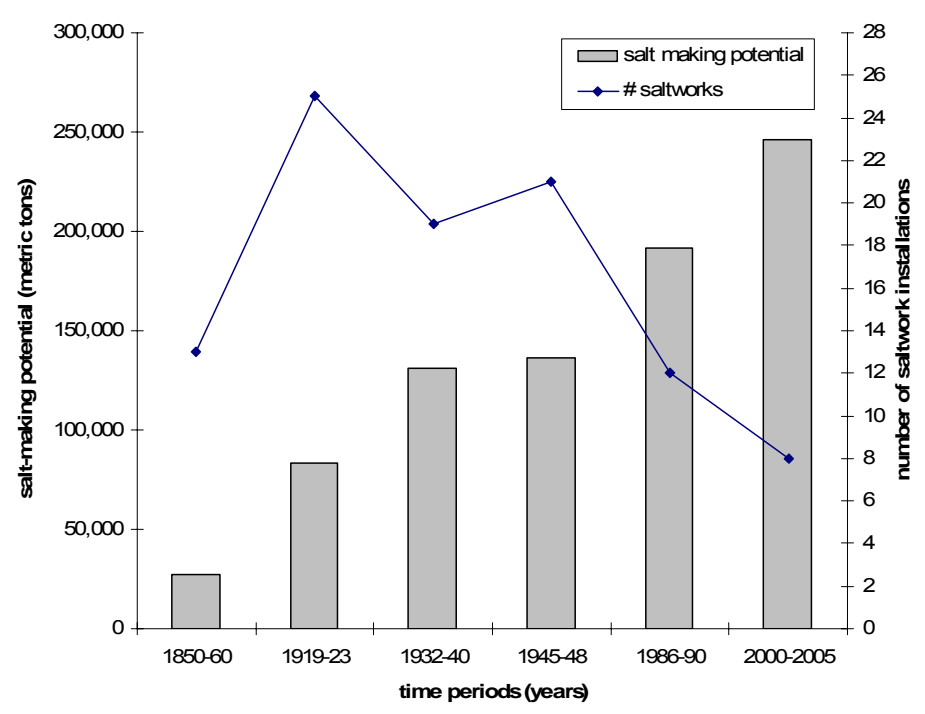

Figure 1. Development of the annual salt making potential and the number of installations of the state saltworks of Greece in different periods during $19^{\text {th }}-20^{\text {th }}$ century. Original data before 1950s are from Mandilaras (1951) 
necessarily imply absence of relevant natural resources. Indeed, some inland salt-springs produced salt in the antiquity in Greece (Petanidou 1997a; 2001a). At present, worth to be mentioned for its salt-making potential is the Monolithi salt deposit in Epirus, which has never been used as a salt resource (Petanidou, 1989). There may be two reasons for that: first, the lack of technical know-how in Greece; and second, the state monopoly which could afford a rigorous control on the salt-making business on the coast rather vs. a more complex interior (Mandilaras, 1951; Petanidou, 1997a).
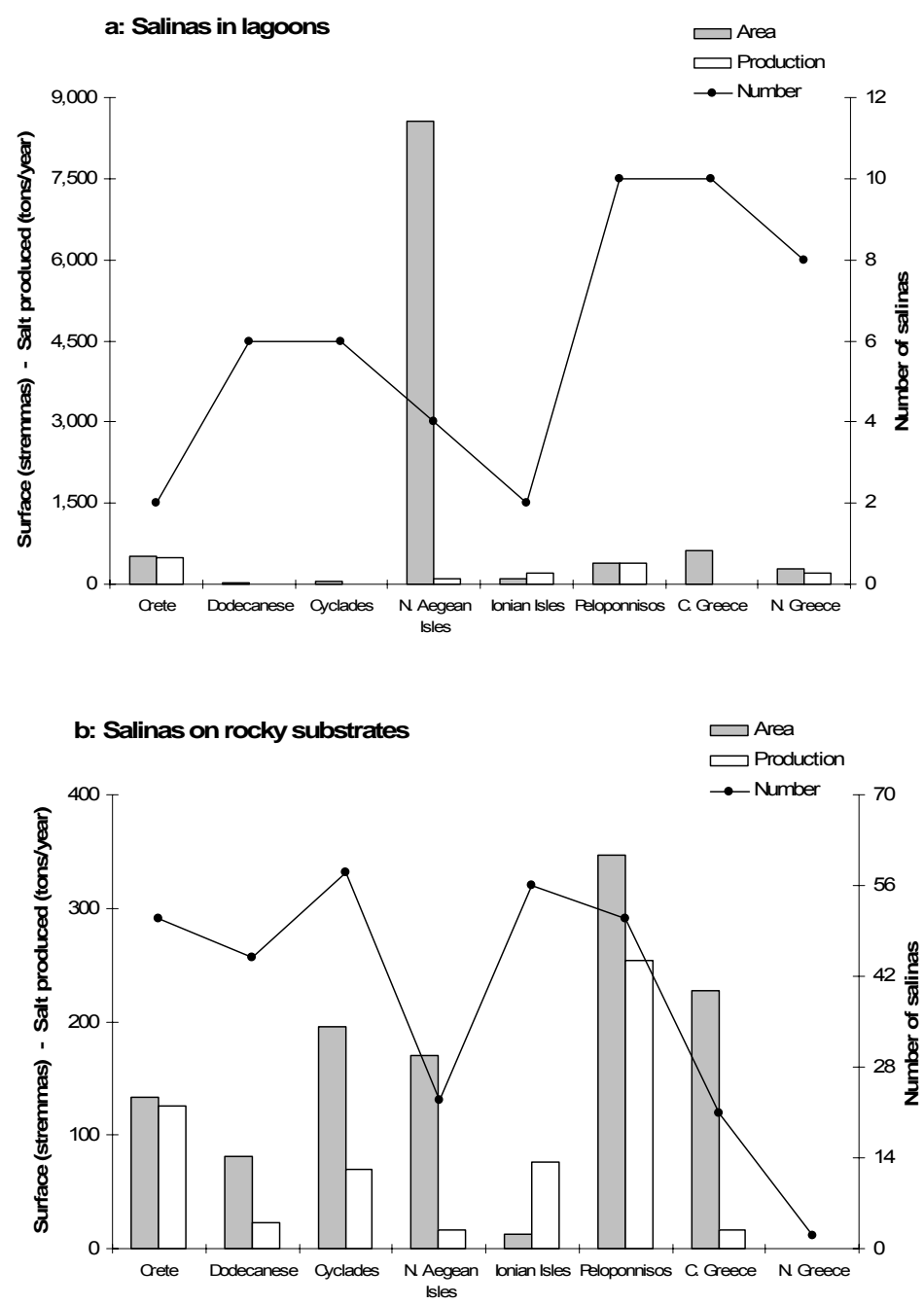

Figure 2. Primitive salinas in lagoons (a) and on rocky substrates (b) found in the major geographical departments of Greece: Crete, Dodecanese, Cyclades (including Hydra, Spetsae, and Aegina islands), N. Aegean islands, Ionian islands (including Kythera and Antikythera), Peloponnesus, C. Greece, N. Greece. We give total number of salina facilities, total surface (in stremmas; 1 stremma $=0.1 \mathrm{ha}$ ) and production potential for the period before the 1960s

A third conclusion is that the largest and most productive saltworks have been mainly limited to the mainland, not the islands. This is because productive saltworks not only need favorable climatic conditions, but also huge flat expanses at sea level, where soil is of low permeability. Such expanses are not easily available in a mountainous country like Greece, which explains the relatively low number of large saltworks that have operated in the country (28). Approximately half and the largest of them are located on flat alluvial coasts with their natural lagoons silted up by rivers (Map 1). This is not exclusive to Greece, and applies equally to the wider Mediterranean (Petanidou, 1997a). 

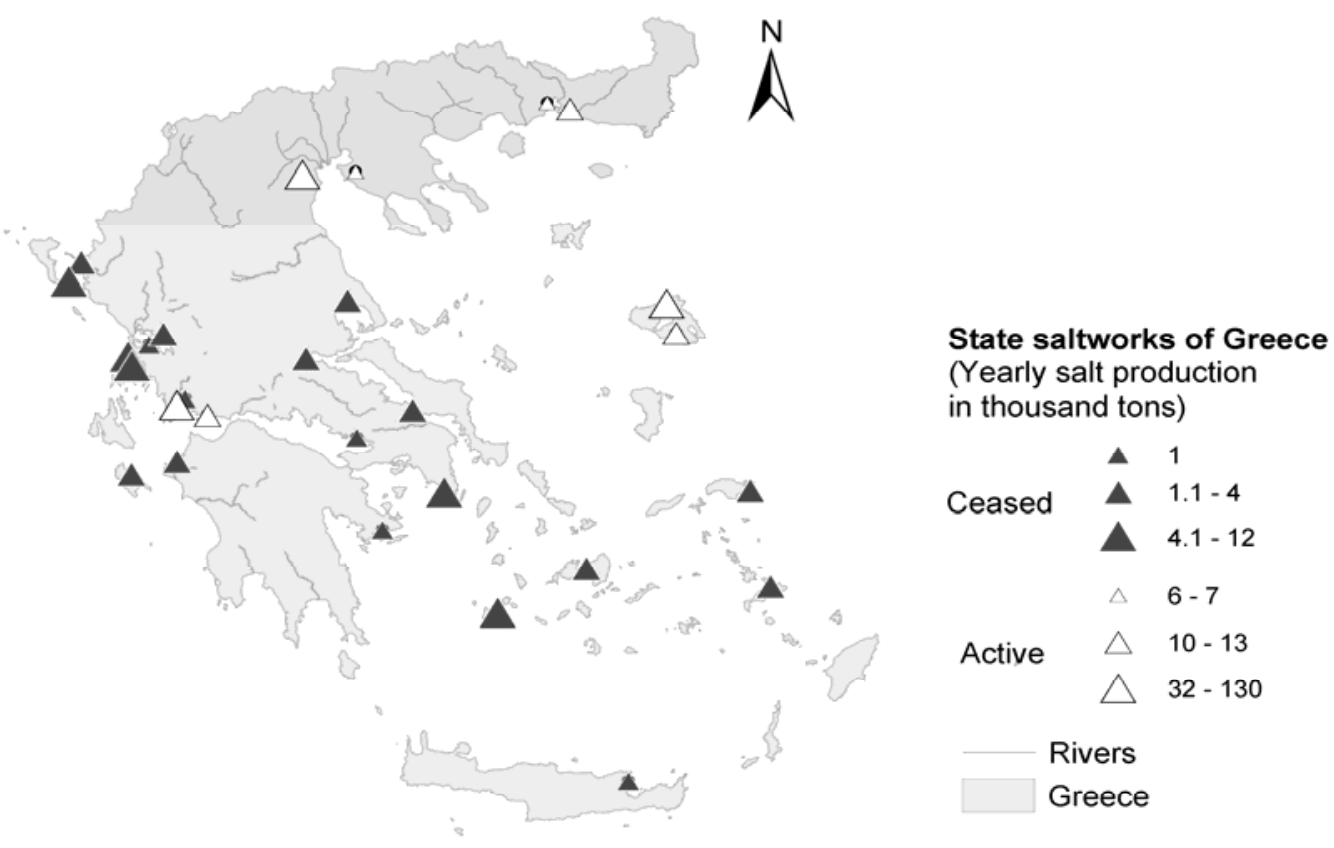

Map 1. The state saltworks that have operated in Greece since the formation of the Greek State (1831) distinguished in ceased and still operating ones

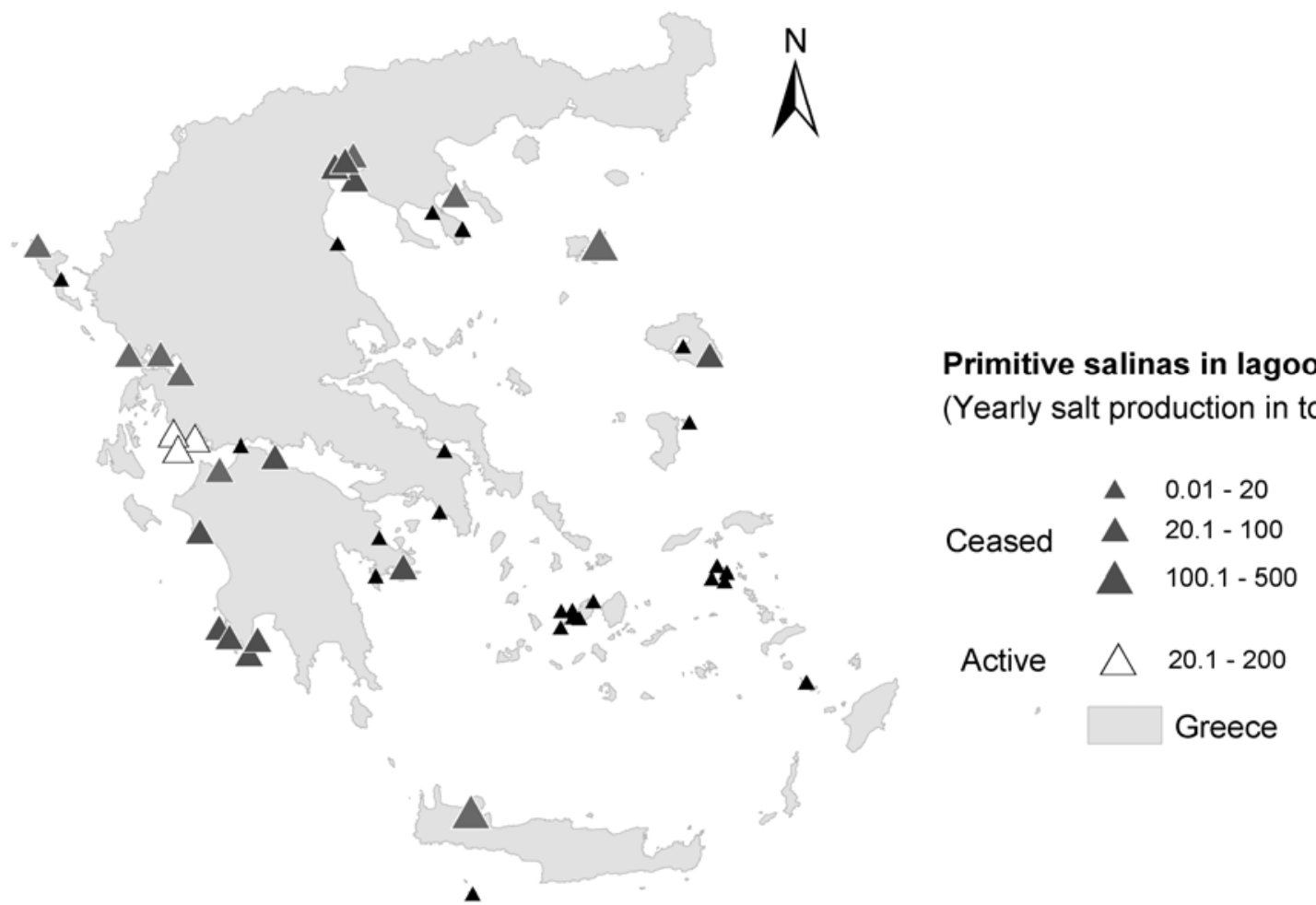

Map 2. Salt-making sites (ceased and operational) located on the earthy substrate in lagoons all over Greece, in all cases managed by locals, not by the Greek State 


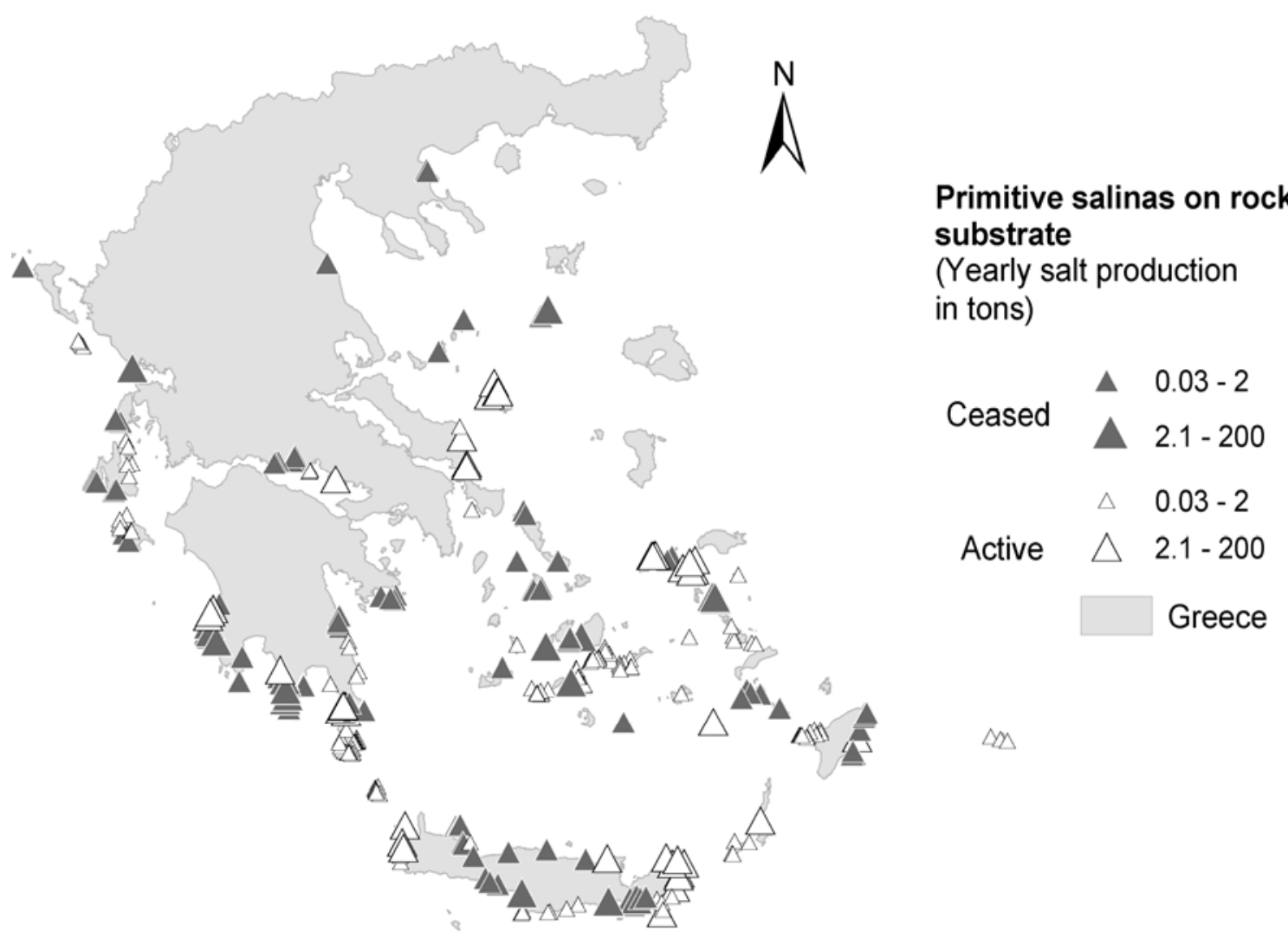

Map 3. Salt-making sites (ceased and operational) sculptured on the rocky coasts of Greece, in all cases managed by locals, not by the Greek State

Small flat expanses in lagoons have been widely used for salt-making in Greece, as large ones were often unavailable. Such expanses are scattered all over the country (48), created from a cut-off rocky coast with small bays, full of alluvial soil deposited by very small rivers or streams. These primitive salinas have never been of national interest. Worth mentioning, both as a name and site of historical interest is the salina of Potamos, meaning "river", in Kerkyra (Map 2), which has been exploited principally by the Venetians (Hocquet, 1982).

The fourth conclusion is that primitive salinas carved on rocky substrates are scattered all over the country, thus constituting the most numerous salt-making resource throughout Greece (Map 3).

\section{Typology of salt-making facilities}

Considering that inland salinas and salt mines are absent, the differential typology of the saltmaking facilities in Greece cannot be defined by geographical location, fuel and brine source used. However, it can be defined by their substrate and size, as well as by the method employed for salt-making.

The soil substrate of the salt-making facilities in Greece is either clayey to sandy (i.e. in lagoons) or pure rock bearing natural or manually-sculptured basins functioning as crystallizers.

The size of a salt-making facility varies according to the space that is available. Those that are difficult to carve (i.e. on coastal rock) are small and relatively simple in operation, composed of one simple or a cluster of basins. Similarly, the size of the facilities operating in lagoon areas depends largely on the flat expanses available varying from some few square meters to some dozens of thousands of hectares (see also Sadoul et al., 1998). Normally the 
large ones can encompass quite a few dozens of evaporation basins which are well separated from the crystallizers.

In all the above facilities, salt is either self-formed without any human intervention, yet in some cases the production is facilitated manually. The extent of human intervention may range from simply widening the rock basins where self-formed salt is deposited, up to substantially managing the soil bottom and the brines to accelerate seawater evaporation.

As a result, all salt-making facilities in Greece can be grouped as to their typology into the following groups: saltworks, that are fully mechanized (seven in number) or semi-mechanized (21); primitive salinas in lagoons with little or without human intervention (48) and primitive or artisanal salinas on coastal rocks without or with meagre to substantial human intervention (307).

Below we treat separately saltworks (viz. the above $7+21$ ) from the remaining salt-making sites. The first, hereafter referred to as state saltworks, have been highly productive and of national importance and they have been operating under the ownership, control and, at times, the management of the Greek State (except for the saltworks of Tourlis belonging to a local authority). The remaining 48+307 (hereafter referred to as non state salinas) are sites of extensive salt production that have been always of local importance.

\section{Developments in the geography of salt-making in $19^{\text {th }}-20^{\text {th }}$ centuries \\ State saltworks}

State saltworks have been organized and operated in a systematic way since the formation of the Greek State in 1831. All of them belong to the lagoon type, i.e. littorals naturally endowed with flat and sandy expanses that have been artificially expanded and covered with semiimpermeable soil. Having a relatively high potential, these facilities developed under the continuous management or/and interest of the state into partially, then into fully mechanized saltworks. Interestingly, since the regency of the King Otto, in mid $19^{\text {th }}$ century, all state saltworks were subjected to the state monopoly with salt taxes constituting thereafter the main state revenue (Mandilaras, 1951). For instance, it was the salt that became accountable for the national debts after the defeats of the wars of 1897 and 1922 against the Ottoman Empire and Turkey, respectively, as well as for the 1924 refugee loan (Mandilaras, 1951; Petanidou, 1997a).

Because of their economic importance, state saltworks have been continuously taken care and invested upon, with their salt-making potential steadily increasing (Figure 1). At first, such an increase resulted through the annexation of newly liberated territories (Ionian islands in 1864; Crete in 1908; Macedonia, Thrace, Thessaly, Epirus and N. Aegean islands in 1912; Dodecanese in 1947) to Greece. However, the foremost increase came through the state's permanent effort to upgrade and modernize the saltworks which resulted to higher salt exports (Mandilaras, 1951; Petanidou, 1997a). Therefore, from the beginning of the $20^{\text {th }}$ century many state saltworks started to shift from the method of periodical (intermittent) crystallization to continuous crystallization and by mid $20^{\text {th }}$ century all Greek saltworks had adopted continuous crystallization. This, indeed, resulted in gradually higher annual salt yields, although at the same time the number of active saltworks decreased. In total 28 saltworks operated in Greece the last two centuries, but the number of those being simultaneously active never exceeded 25 (Map 1; Figure 1).

A substantial change in the geography of the Greek saltworks took place in 1988-1989, when state monopoly was abolished: out of the 16 working saltworks only eight were considered operational and reformed (e.g. fully mechanized) whereas the remaining were closed down (Petanidou, 1994). It is remarkable that the domestic salt production in Greece could then hardly satisfy half of the needs of the country, the rest covered by imports. This situation continues today as then.

Non state salinas

Apart from the state saltworks, salt in Greece has been produced extensively by a large number of primitive and artisanal salinas spread throughout the Greek coastline. Two major groups are distinguished: 
1. Primitive salinas operating on earthy substrate as part of major lagoon formations. These salinas never operated under the control of the Greek State, although they might have been relatively large, such as those of Dymi (province of Achaia), Pyrgos (lleia), Methoni and Koroni (Messinia), Potamos (Kerkyra), Souda (Crete) and Voula (Attica) (Map 2), whereas some of them had been producing salt systematically since the antiquity and especially under the Venetian and the Ottoman regimes.

2. Salinas operating on rocky substrate employing a variety of methods and degree of human intervention. They encompass a wide span of salina types from the most primitive salterns (locally known as goúrnes) producing self-formed salt to the more elaborated artisanal salinas (see above; Map 3). Salinas on rocky substrate produced mainly afrálatso (meaning fine salt skimmed from the brine), whereas the heavy-crystal karaválatso (meaning shipped salt, i.e. suitable for long trade trips), derived from salinas of the lagoon type, and mainly from the state saltworks (cf. also Saitas and Zarkia 2001).

Given their relatively vast expanses of the lagoon salinas it is no wonder that their salt-making potential is much higher than those of the salinas sculptured on rocky substrates. Maps 2-3 show an overview of the geographical distribution and level of salt production for different salina types: average surface of the lagoon salinas is $22.0 \pm 17.65$ ha (range: $0.05-850 ; n=$ 48 ) yielding $30.0 \pm 11.83$ metric tons of salt per year (range: $0.1-500$ ); average surface of salinas on rocky substrates is $0.4 \pm 0.09$ ha (range: $0.0003-20 ; n=307$ ) yielding $1.9 \pm 0.41$ metric tons of salt per year (range: $0.007-90$ ).

There is a remarkable difference as to the type, size and potential of the salt-making sites located on the islands and the mainland of Greece: In general, it can be inferred that islands together with long peninsulas, exceed by far the mainland as to the number, surface and productivity of the primitive/artisanal salinas sculptured on rocks (Table 2). In fact, these salinas are massively located at the southern part of the country (particularly crowded is Peloponnesus and southern islands) and less in the mainland (Map 3, Figure 2a).

Primitive salinas in lagoons, although equally represented in number both in the mainland and on the islands, they yielded more on the islands ground (Table 2). This is possibly due to the differential lack of interest by the Greek State to invest in such small salt producing areas scattered throughout the Greek archipelago vs. the lagoons in the mainland that would be easier to develop (e.g. enlarge facility, transfer salt) and to control. In contrast, local interest for such facilities was greater on the islands for a variety of reasons discussed below.

\section{Using and trading local salt}

While all salt produced in state saltworks was meant for export at the national and international scale, most of the salt produced extensively, i.e. on lagoon or rocky substrates, was meant to cater only for the local needs. Even so, some of the primitive and artisanal salinas have been of prime importance for the local economy and culture.

Local needs included mainly domestic as well as artisanal to small industrial uses all over Greece. Salt was used as the basic food condiment; animal food; cheese and olive oil making; salting of fish, meat, vegetables, olives and other perishables; use as a drug and remedy for illnesses; and salting of the new-born children. Yet, salt has been an important commodity for local craftsmanship such as ceramic glazing and tanning of skins. In the islands of the Aegean traditional specific uses of salt included salt-coating the stonewalls in the inner side of water wells and salt-covering the roofs of the buildings, both aiming at halting any growing vegetation that might harm the constructions.

In rural societies salt continued having an important role throughout the $20^{\text {th }}$ century, which was the reason why it also kept its exchange value until the 1960s like in the old times in many parts of the country. Locally produced salt was exchanged for other goods and everyday commodities, such as food (e.g. cereals, olive oil, pulses, wine, fresh and dry fruits, durable vegetables as potatoes and tomato puree, fish, as well as dairy products, especially cheese). This has been particularly pronounced in remote areas, such as islands and long peninsulas, as indicated by their high number of salinas trading salt: out of all salt-making facilities found on rocks and produced salt that was traded locally or nationally, 95\% (i.e. 100 facilities) were located on islands or peninsulas. Similarly, islands and peninsulas 
accommodated $71 \%$ of the country's lagoon salinas producing salt that was also traded (i.e. 12 facilities). State saltworks, on the other hand, chiefly located on the mainland (Map 1), had principally an exporting character. All these facts underline the importance of locally produced salt in remote areas, for which salt continued having currency significance as in the antiquity (Petanidou, 1997a). The exchange value of salt dropped after 1960s and disappeared soon after.

\section{Abandonment of the salt-making business \\ State saltworks}

Although their salt yield potential increased with time, the number of active saltworks in Greece has suffered a dramatic decline, especially in the second half of the $20^{\text {th }}$ century (Figure 1). This abandonment does not reflect much the local changes, however. It is rather explained as a result of continuous and profound social and technological changes at different levels, particularly in relation to systems and means of production, a process commonly known as "globalization" that modern societies have undergone during the second half of the $20^{\text {th }}$ century. Thus, the development model of salt-making business in the State saltworks of Greece has gone through two phases. First, intensification (i.e. shift from intermittent to continuous evaporation during the first half of the $20^{\text {th }}$ century); and second, mechanization (e.g. gradual introduction of engines to pump brine, as well as to collect and transfer salt, which finally replaced human labor used until then). Although there have been efforts to industrialize most State saltworks and reduce further production costs, this was finally not always feasible in Greece due to political upheavals and land shortage (Petanidou, 1997a).

In the 1980s large changes occurred in the world salt market. Following industrialization processes, salt production started to be managed internationally and trans-nationally (Peraud, 2002; Neves et al., 2005). As an example, the last decade the largest coastal salinas in Spain have been exploited by two multinational companies (Instituto Geológico y Minero de España 2003). The above, combined with the global changes in long-distance trade, together with the fact that salt was no more indispensable for food conservation (due to refrigeration and other alternative methods), abolished salt from the rank of prime commodities it was considered before WW II. The final slap came from the halt of protectionism by the state monopoly which gradually ended in the 1980s, as done in almost all countries of the Mediterranean Europe.

Today the majority of the saltworks ever operated in Greece are abandoned (71.5\%; Map 1). Many of them have not changed land use, being still characterized as "saltworks" albeit with no management. The ongoing discussion explores whether and on what economic basis restarting salt production would be a sustainable solution in view of preserving the historical, cultural, and ecological values of these salinas (Petanidou, 1987, 2009; 1997a,b,c,d; Marín and Orlando, 1997; Sadoul et al., 1998; Walmsley, 2000; Petanidou and Vayanni, 2002; Petanidou et al., 2002a; Kalafatis et al., 2003; Dahm, 2005a; Sovinc, 2005).

Non state salinas

Although the exact times of abandonment are not available, the majority of the primitive/artisanal salinas in Greece seem to have ceased activity between WW II and 1960s (Table 2). According to the respondents, the low price of salt stands among the critical reasons of abandonment of these salinas - a compound effect of technological achievements in the making and transportation of salt, as well as its significance as a basic means of food conservation. Under such conditions, instead of the important commodity it was previously, salt descended to a cheap product supplied efficiently to the extremities of the country regardless their remoteness. It is remarkable that salt in non state salinas was illegally produced and traded as long as salt had a high price (Saitas and Zarkia, 2001). Low prices, however, discouraged locals from continuing a long lasting traditional activity, who finally seized on newly arising, less labor-intensive opportunities such as tourism. In fact, the ensuing land use change is comparable to those associated with other natural resources which have been traditionally managed in the Mediterranean and the Aegean up to the WW II, then gradually abandoned as rather unprofitable: acorn collection, sponge fishing, cultivation on terraces and many others (Grove and Rackham, 2002; Petanidou, 2004; Petanidou et al., 2008). 
The decline in salt-making business had serious repercussions all over the Greek territory. Interestingly, islands and the mainland suffered contrasting land use changes (Table 3):

1. Salt-making business in lagoons was hit almost everywhere in Greece and particularly on the islands ground. Remarkably enough, the lowest decline occurred in C. Greece, where costal tourism is less developed than anywhere else in the country (Spilanis, 2003). This may be explained by the high competition for coastal land use and for human resources imposed by tourism. In reality, many tourist developments in the Aegean are just located at an "Alyki", a place name meaning "salina", with the actual salina lying dormant nearby (e.g. Paros, Samos).

2. Salt-making business on rocks was affected less on the islands and peninsulas compared to the mainland. Peloponnesus and Cyclades are exempted from this rule, which can be attributed to competition for labor hands due to summer tourism. However, in many areas the value that is less affected is the number of sites, implying that in many of them salt continues to be harvested, albeit only partially and occasionally. Nonetheless, the continuing salt collection in remote areas is interesting as an activity. Here we summarize some explanatory drivers:

a. Salt collection or artisanal making represents a long tradition that has been taking place outside the control of authorities, state monopoly, and trade centers. In such sites salt gaining is part of the people's cultural identity, as it is in Mani, Peloponnesus (Saitas and Zarkia, 2001).

b. Salt-making sites constitute marginal land that is difficult to exploit otherwise, therefore there is no competition among different potential uses.

c. The activity can be simple, requiring little labor and no investment: in many cases it consists of mere collecting the self-formed salt from the salterns (Saitas and Zarkia, 2001).

d. Collecting salt constitutes a secondary or tertiary occupation contributing to a higher income for the multi-active islander families.

e. Local salt needs may be higher in islands than in the mainland, as salt in islands caters for the preservation of traditional food and tourist products (e.g. salting of fish, cappers, and dried tomatoes).

f. In many cases self-formed and hand-collected stuff is considered healthier or/and of higher gastronomic value than the industrial one. Although there are no data for the rock salterns of the Aegean, the artisanal salt of Guérande is considered tastier and perhaps healthier (Perraud, 2002; Petanidou et al., 2002c). This is the main motive for the increasing production of salt harvested the last few years on the rocks of Kythera and the peninsulas of Peloponnesus, which satisfies a growing Swedish market (Petanidou, unpublished data).

\section{Epilogue: what saltscapes for the future?}

The example of land use change of saltworks and salinas due to alternative, more profitable opportunities, is typical of many other natural resources in Greece and the Mediterranean basin: traditionally managed as long as they were profitable, i.e. roughly until WW II, then gradually abandoned (Horden and Purcell, 2000; Grove and Rackham, 2002; Pinto-Correia and Vos, 2004; Petanidou, 2004; Petanidou et al., 2008).

The pattern of land use change in the salt-making business of Greece did not differ from other European countries of the Mediterranean. In Spain, as in Greece, the once extended complex of salt-making sites shrunk progressively in the course of the $20^{\text {th }}$ century, although the overall productivity increased (Hueso and Neves, 2005). In both these countries there has been a gradual shift from a geographically dispersed network of salt producing sites catering for the local/regional needs of the country to a consolidated network of sites fulfilling certain economic criteria (e.g. productivity, access, and distance from the consumption centers). It is possible that this network will be further reduced in the future as a result of economic discrepancies. At least for Greece, the previsions are not good as only half of the eight saltworks operating today in the country are optimistically competitive.

Considering the positive side of the salt-making business today, we recognize that Greece, and probably all the Mediterranean countries alike, still possess high quality saltscape 
resources. Namely they consist of: (i) the saltworks and salinas that are still in operation; (ii) the dormant saltworks all over the country and in particular on islands; and (iii) the ceased but still recognizable artisanal salinas equally on earthy and rocky substrates. All the above saltscapes represent important capital (cultural, ecological, and economic) at all levels and scales, from local to global. Given their vulnerability, in terms of loss of craftsmanship and cultural heritage, as well as impoverishment of landscape and biodiversity, these structures need particular attention and imminent care in order that their values are preserved for the benefit of the next generations.

Several efforts have been undertaken aiming at drawing the attention of local authorities and managers to the values of the salinas and saltworks. The accumulated literature is rich and chiefly concerns the preservation and management of these threatened resources using salt business as an alternative pole for local development (Luengo and Marín, 1994; Marín and Orlando, 1997; Sadoul et al., 1998; Korovessis and Lekkas, 2000; Petanidou and Vayanni, 2002; Petanidou et al., 2002a; Kalafatis et al., 2003; Neves et al., 2005; Lekkas and Korovessis, 2006). As a result, there have been cases in which abandoned salinas were restored and rehabilitated. These were mostly small artisanal salinas, such as those in the Canary Islands, Iberian Peninsula, Italy and Slovenia (Luengo and Marín, 1994; Neves et al., 2005; Hueso-Kortekaas, personal communication). A positive result in most of these rehabilitated sites is the creation of salt museums and information centers focused on their cultural, ecological, and diachronically economic value (Dahm, 2005b; Nasiadis, 2005; Buron, 2005, Petanidou, 2009). However, there has been no concerted action to apply a management scheme that equally considers the above values altogether. Even the ecological management remains still an unachievable target in many saltworks, despite the enormous evidence on their ecological significance and the sporadic efforts employed in order to rehabilitate them (Britton and Johnson, 1987; Kastritsi-Katharios, 1991; Velasquez, 1992; Martos and Johnson, 1996; Thibault et al., 1997; Sadoul, 2002; Rufino, 2005b).

It is reasonable that abandoned saltworks and salinas are difficult to re-operate aiming at salt alone as economic profit. However, appreciable characteristics of these saltscapes may be compatible and thus could be combined with sustainable tourism. Such old salt-making sites preserved as habitats endowed with unique wetland qualities, can be used as sites of special gastronomic and cultural values, as landscapes for creation and recreation, as places of knowledge through their salt museums, and as areas where environmental education is sensible (Petanidou, 1997a; Petanidou et al., 2002a; ALAS project, 2002; Neves et al., 2005; Crisman et al. 2009; Petanidou, 2009). For those doubting that the above are possible to perform, the brilliant paradigm of Guérande (Brittany, W. France) proved in practice that such an experiment can be a great success (Perraud, 2002). We trust that the Guérande model is the only way that may lead to the preservation of the dormant saltscapes of the Aegean and many others throughout the Mediterranean basin.

\section{ACKNOWLEDGEMENTS}

This article is dedicated to the late Zora Žagar, ethnologist and persuaded salina lover. For more than two decades Zora has been the soul of the first salt museum in the Mediterranean basin, the Museum of Salt-making in Piran, Slovenia.

The senior author wishes to thank all collaborators and students that participated and contributed to the study project, in particular Hjalmar Dahm, Nikos Soulakellis, Kostas Karystinakis, Nikos Koziakis, loulia Kondyli, Yiota Spastra, and Varvara Vounatsou. She gratefully acknowledges the contribution of Reinhardt Klein and Katia Hueso-Kortekaas in different stages of the project. Many thanks go to all the interviewees throughout Greece, especially to Dinos Papadelias, Haralambos Diakomihalis, and Theophanis Pavlakis (island of Nisyros); Koula Dounia (Kalymnos); Dimitrios and Christina Nitis (Kastelorizo); Antonis Kontoleon (Kythera); Christos Landrou (Samos); Elias Gateas (Mani, Peloponnesus); Spyros Mitrogiannis (Paros); Melianos Matthaios (Patmos); Manos Mastrogiorgis (Kos); Stelios Eleftheriou, and loannis Psouchlos (Ag. Paraskevi, Lesvos); Spiros Kapris, Kyriakos Voyiatzis, and Parthenis Dracos (Anchialos/Pomorie, Bulgaria); Dimitrios Viliotis (Hellenic Saltworks S.A., Athens). The study was financially supported by the European project ALAS: ALI About Salt (http://www.aegean.gr/alas/, 1999-2002; ECOS-OUVERTURE Program). 


\section{REFERENCES}

Adshead S.A.M. (1992) Salt and civilization, MacMillan Academic and Professional Ltd., Houndmills, London.

ALAS project (2002) http://www.aegean.gr/alas/ (last access 25 July 2007).

Altimir-Bolva J. (1945) La sal en el mundo, Ediciones al servicio de la industria salinera, Barcelona.

Amorim I. (ed.) (2005) I seminario internacional sobre o sal português, Instituto de Historia Moderna da Universidade do Porto, Porto.

Bergier J.-F. (1982) Une histoire du sel, Office du livre, Fribourg, Suisse.

Britton R.H. and Johnson A.R. (1987) An ecological account of a Mediterranean salina: the Salin de Giraud, Camargue (S. France), Biological Conservation, 42, 185-230.

Buron G. (1999) Bretagne des marais salants - 2000 ans d'histoire, Skol Vreizh, Morlaix.

Buron G. (2005) Le musée des Marais Salants: 2000 ans au service du renouveau des marais salants et du sel de Guérande, In: I seminario internacional sobre o sal português, Amorim I. (ed.), Instituto de Historia Moderna da Universidade do Porto, Porto.

Casal U.A. (1958) Salt, Monumenta Nipponica, 14, 61-90.

Crisman T.L., Takavakoglou V., Alexandridis T., Antonopoulos V. and Zalidis G. (2009) Rehabilitation of abandoned saltworks to maximize conservation, ecotourism and water treatment potential, Global NEST Journal, 11(1), 24-31.

Dahm H. (2005a) An ecological view of the salinas of Lesvos. In: ALAS (All About Salt) - Salt and salinas in the Mediterranean, Neves R., Petanidou T., Pinto S. and Rufino R. (eds.), Municipality of Figueira da Foz - ALAS, Lisbon.

Dahm H. (2005b) Salt museums, In: ALAS (All About Salt) - Salt and salinas in the Mediterranean, Neves R., Petanidou T., Pinto S. and Rufino R. (eds.), Municipality of Figueira da Foz - ALAS, Lisbon.

Davis J.S. (2000a) Solar Saltworks - An environmentally friendly industry, In: Saltworks: Preserving saline coastal ecosystems, Korovessis N. and Lekkas T.D. (eds.), Global NEST Hellenic Saltworks S.A., Athens.

Davis J.S. (2000b) Structure, function, and management of the biological system for seasonal solar saltworks, Global Nest: the International Journal, 2, 217-226.

Davis J.S. (2009) Management of biological systems for continuously-operated solar saltworks, Global NEST Journal, 11(1), 73-78.

Escacena-Carrasco J.L. and Rodriguez de Zuloaga M. (1994) La Marismilla - Una salina neolítica en el Bajo Guadalquivir, Revista de arqueología, 9(89), 14-24.

Escacena-Carrasco J.L., Rodríguez de Zuloaga-Montesino M. and Ladrón de Guevara-Sánchez I. (1996) Guadalquivir salobre - Elaboración prehistórica de sal marina en las antiguas bocas del río, Confederación Hidrográfica del Guadalquivir, Sevilla.

Evagelopoulos A., Spyrakos E. and Koutsoubas D. (2009) Phytoplankton and macrofauna in the low salinity ponds of a productive solar saltworks: spatial variability of community structure and its major abiotc determinants, Global NEST Journal, 11(1), 64-72.

Galinou E. (1999) Study of temporal and spatial distribution of waterfowl in the saltworks of Kalloni, Lesvos island, Greece, Unpublished graduate thesis, Department of Environmental Studies. University of the Aegean, Mytilene.

Geslin T., Lefeuvre J.-C., Le Pajolec Y., Questiau S. and Eybert M.C. (2002) Salt exploitation and landscape structure in a breeding population of the threatened bluethroat (Luscinia svecica) in salt-pans in western France, Biological Conservation, 107, 283-289.

Grove A.T. and Rackham O. (2002) The nature of Mediterranean Europe: an ecological history, Yale University Press, New Haven.

Goutner V. and Papakostas G. (1992) Evaluation of the ornithological importance of the Alyki Kitrous wetland, Macedonia, Greece: A priority for conservation, Biological Conservation, 61, 131-138.

Handrinos G. and Akriotis T. (1997) Birds of Greece, Helm Field Guides - A \& C Black Publishers Ltd., Christopher London.

Hocquet J.-C.(1982) Le sel et la fortune de Venise - Volume 1. Production et monopole, Presses de l'Université de Lille III, Lille.

Hocquet J.-C. and Sarrazin J.-L. (2006) Le sel de la Baie - Histoire, archéologie, ethnologie des sels atlantiques: Presses Universitaires de Rennes, Rennes. 
Horden P. and Purcell N. (2000) The corrupting sea: A study of Mediterranean history, Blackwell, London.

Hueso-Kortekaas K. (2004) Propuesta de plan de uso público del complejo lagunar de la salada de Chirpana (Zaragoza), Serie Técnica, Informes Medioambientales no 1, Edición No Venal, Spain.

Hueso-Kortekaas K. (2005) Annual report 2005 of the Cultural Association "Friends of island salinas". Guadalajara, Madrid.

Hueso K. and Neves R. (2005) Inland salinas in the Iberian peninsula, In: ALAS (All About Salt) Salt and salinas in the Mediterranean, Neves R., Petanidou T., Pinto S. and Rufino R. (eds.), Municipality of Figueira da Foz - ALAS, Lisbon.

Instituto Geológico y Minero de España, (2003) Panorama minero: Sal común, In http://www.igme.es/internet/RecursosMinerales/panoramaminero/minerales/salcomun03.htm (last accessed 25 July 2007).

Instituto Tecnológico Geominero de España, (1997) Inventario nacional de recursos minerales de cloruro sódico y sales potásicas, Madrid.

Kalafatis T., Petanidou T. and Synodinos Z. (eds.) (2003) Proceedings of the Symposium entitled: Restoration and valorisation of the ceased and non-functional saltworks of the lonian islands (Kerkyra, Lefkas, Zakynthos), Prefecture of Lefkas - Association of Ionian Studies - Nefeli Publications, Athens (In Greek).

Kastritsi-Katharios I. (ed.) (1991) Environmental study and upgrading works of the Messolonghi saltworks, Report to the Hellenic Saltworks S.A., vol. I, L.Y.E., Athens (in Greek).

Korovessis N. and Lekkas T.D. (eds.) (2000) Saltworks: Preserving saline coastal ecosystems In: Proceedings of the Post-Conference Symposium of the $6^{\text {th }}$ International Conference on Environmental Science and Technology, Global NEST, Athens.

Kurlansky M. (2003) Salt: a world history, Penguin Books Ltd., New York.

Lekkas T.D. and Korovessis N. (eds.) (2006) Proceedings of the 1st International Conference on the ecological importance of solar saltworks, 20-22 October, Santorini, Global NEST, Athens.

Lekkas T.D. and Korovessis N. (2009) Solar saltworks' wetland function, Global NEST Journal, 11(1), 49-57.

Lemonnier P. (1984) Paludiers de Guérande: production du sel et histoire économique, Musée national d'histoire naturelle, Mémoires de l'Institut d'Ethnologie 22, Musée de l'Homme, Paris.

Luengo A. and Marín C. (1994) El Jardín de la sal., Ecotopía Ediciones Tenydea, S.L., Santa Cruz de Tenerife.

Malpica-Cuello A. (1981) Las salinas de Motril (Aportación al estudio de la economía salinera del reino de Granada a raíz de su conquista), Baetica, 4, 147-165.

Malpica-Cuello A. (1991) Fiscalidad y comercio de la sal en el reino de Granada en la edad media, In: Das Salz in der Rechts und Handelschichte, Hocquet J.-C., Palme R. and lingenhaeff W. (eds.), Berenkamp, Schwaz.

Mandilaras K.I. (1951) The saltworks of Greece and their development from 1824-1949, National Print House of Greece, Athens (in Greek).

Marín C. and Orlando G. (eds.) (1997) Nature and Workmanship - Artificial wetlands in the Mediterranean coast, Insula - DG XI - UNESCO, Santa Cruz de Tenerife.

Martos M.R. and Johnson A.R. (1996) Management of nesting sites for Greater Flamingos, Colonial Waterbirds, 19, 167-183.

Masero-José A. (2003) Assessing alternative anthropogenic habitats for conserving waterbirds: salinas as buffer areas against the impact of natural habitat loss for shorebirds, Biodiversity and Conservation, 12, 1157-1173.

Masero-José A. and Pérez-Hurtado A. (2001) Importance of the supratidal habitats for maintaining overwintering shorebird populations: how redshanks use tidal mudflats and adjacent saltworks in southern Europe, The Condor, 103, 21-30.

Multhauf R.P. (1978) Neptune's gift - A history of common salt. Johns Hopkins studies in the history of technology: New series no 2., Johns Hopkins University Press, Baltimore, London.

Nasiadis A. (2005) Salt museums and tourism in Europe, Unpublished graduate thesis, Department of Geography. Mytilene: University of the Aegean (in Greek).

Neves R., Petanidou T., Pinto S. and Rufino R. (eds.) (2005) ALAS: All About Salt - Salt and salinas in the Mediterranean, Municipality of Figueira da Foz - ALAS, Lisbon. 
Pérez-Hurtado A. and Hortas F. (1993) Trophic activity of waders wintering in salinas and fishfarms in Cadiz Bay, Doñana Acta Vertebrata, 20, 103-123 (in Spanish).

Perraud C. (2002) Une stratégie de marketing pour le sel traditionnel: le cas de Guérande, In: Salt and salinas as natural resources and alternative poles for local development - Proceedings of the ALAS Final Conference, Petanidou T., Dahm H. and Vayanni L. (eds.), University of the Aegean, Mytilene.

Petanidou T. (1987) The Saltworks of the Aegean, Report to the Ministry of Youth, Aristotle University of Thessaloniki, Thessaloniki (in Greek).

Petanidou T. (1989) Environmental impact assessment from the scheduled installation of saltworks in Amvrakikos gulf aiming at the exploitation of the Monolithi salt by mining, Report to the Hellenic Saltworks S.A., Aristotle University of Thessaloniki, Thessaloniki (in Greek).

Petanidou T. (1991) The saltworks of Kalloni, Kessani, Kitros, M. Emvolo, Messi, and Polichnitos from the ecological viewpoint, Report to the Hellenic Saltworks S.A., Aristotle University of Thessaloniki, Thessaloniki (in Greek).

Petanidou T. (1994) Conserving nature, we produce salt throughout Greece, Hellenic Saltworks S.A., Athens.

Petanidou T. (1997a) Salt - Salt in European History and Civilization, Hellenic Saltworks S.A., Athens.

Petanidou T. (1997b) Ecological management of the saltworks of Messolonghi: Protection of the environment and public awareness, In: Sustainable development along with public awareness, Mavrellis K. (ed.), Ministry of National Education and Religion - Prefecture of Aitoloakarnania Messolonghi (in Greek).

Petanidou T. (1997c) European saltworks at the threshold of the 21st century - Importance, threats and remedies, In: Nature and Workmanship - Artificial wetlands in the Mediterranean coast, Marín C. and Orlando G. (eds.), Insula - DG XI - UNESCO, Santa Cruz de Tenerife.

Petanidou T. (1997d) Management of the Messolonghi saltworks habitat. In Nature and Workmanship - Artificial wetlands in the Mediterranean coast, eds. C. Marín and G. Orlando, Marín C. and Orlando G. (eds.), Insula - DG XI - UNESCO, Santa Cruz de Tenerife.

Petanidou T. (2000) The postmodern saline landscape in Greece and the European Mediterranean: salinas for salt or what? In: Saltworks: Preserving saline coastal ecosystems, Korovessis N. and Lekkas T.D.eds., Global NEST - Hellenic Saltworks S.A., Athens.

Petanidou T. (2001a) The Geography of use and making of salt in the Greek World, In: The Greek Salt - Proceedings of the $8^{\text {th }}$ Symposium of the Cultural and Technological Foundation of ETBA, Cultural and Technological Foundation of ETBA, Athens (in Greek with English summary).

Petanidou T. (2001b) Mediterranean salinas: tradition and sustainable use, MedWet Newsletter Mediterranean Wetlands, 15, 4-6.

Petanidou T. (2002) Typology of the Greek Salinas, ALAS Newsletter, 5, 8-9 (also available at http://www.aegean.gr/alas/NEWSLETTER5.pdf - last access 25 July 2007).

Petanidou T. (2004) Exploiting salinas and salt with view of sustainable development: the experience from the ALAS project, In Proceedings of the Symposium entitled: Protected areas, and local development, Zouros N. and losifidis T. (eds.), Natural History Museum of Petrified Forest of Lesvos, Sigri and Thessaloniki (in Greek).

Petanidou T. (2009) Cultural aspects for the conservation of Mediterranean salinas, In Proceedings of the Workshop entitled: Prespa workshop - Towards an integrated approach to the cultural and natural aspects of wetlands, Papayiannis T. (ed.), Med-INA, MedWet and Society for the Protection of Prespes, Athens. Forthcoming.

Petanidou T. and Vayanni L. (2002) Saltworks, cultural heritage and local development: arguments for decision-making, ALAS Technical Letter, ALAS, Koper, Slovenia.

Petanidou T., Akriotis T. and Makrodimos A. (1991) Upgrading the Messolonghi saltworks from the ecological point of view - Interim Report to the CEC - Dg XI, Thessaloniki (in Greek).

Petanidou T., Dahm H. and Vayanni L. (eds.) (2002a) Salt and salinas as natural resources and alternative poles for local development - Proceedings of the ALAS Final Conference, University of the Aegean, Mytilene.

Petanidou T., Dahm H., Dalaka A., Vayanni E., Kalafatis T., Arakadaki M., Karystinakis K., Spastra P., Kondyli I., Vounatsou V., Koziakis N., Malliotaki K., Vatzaki E. and Anagnostou S. (2002b) 
Final Technical Report AENAL and EC for the project ALAS: All About Salt, vols. 1-6, University of the Aegean, Mytilene.

Petanidou T., Dahm H. and Neves R. (2002c) Traditionally produced salt: a high quality product. Leaflet. http://www.aegean.gr/alas/leaflets/leaflet3.pdf (last access 25 July 2007).

Petanidou T., Kizos T. and Soulakellis N. (2008) Socioeconomic dimensions of the agricultural landscape change in the Mediterranean: the case of the abandonment of cultivation terraces on Nisyros island, Greece, Environmental Management 41, 250-266.

Pinto-Correia T. and Vos W. (2004) Multifunctionality in Mediterranean landscapes - past and future, In: The new dimensions of the European landscape, Jongman R. (ed.), 155-184. Wageningen UR Frontis Series nr. 4, Springer, Berlin.

Quaranta M., Russo E. and Palmisciano M. (2000) La zona umida dell salina di Margherita di Savoia - Guida naturalistica. Trinitapoli: Regione Puglia - Centro Regionale di Servici Educative e culturali.

Quesada T. and Malpica-Cuello A. (1994) Las salinas de Andalucía oriental en epoca medieval. Planteamientos generales y perspectivas de investigación, Journal of Salt History, 2, 144169.

Rodríguez-Rodríguez E. (2000) Historia de las explotaciones salinas en las Lagunas de Villafáfila. Cuadernos de Investigación Florián de Ocampo, Diputación de Zamora, Zamora.

Rufino R. (2005a) Ecological features of the Mondego estuary and its salinas, In: ALAS (All About Salt) - Salt and salinas in the Mediterranean, Neves R., Petanidou T., Pinto S. and Rufino R. (eds.), 70-71, Municipality of Figueira da Foz - ALAS, Lisbon.

Rufino R. (2005b) Management Plan for Castro Marim Nature Reserve - Case Study, In: ALAS (All About Salt) - Salt and salinas in the Mediterranean, Neves R., Petanidou T., Pinto S. and Rufino R. (eds.), 81-85, Municipality of Figueira da Foz - ALAS, Lisbon.

Rufino R. and Neves R. (1991) Census of Black-winged Stilt Himantopus himantopus breeding in Portugal, Airo, 2, 10-11 (in Portuguese)

Sadoul N. (2002) Ecological management in the Mediterranean salinas: from theory to practical experience. In Salt and salinas as natural resources and alternative poles for local development - Proceedings of the ALAS Final Conference, Petanidou T., Dahm H. and Vayanni L. (eds.), 73-82, University of the Aegean, Mytilene.

Sadoul N., Walmsley J.G. and Charpentier B. (1998) Salinas and nature conservation, MedWet series $\mathrm{n}^{\circ}$ 9, Conservation des zones humides méditerranéennes, Tour du Valat, Arles.

Saitas Y.K. and Zarkia K.I. (2001) Places and know-how of salt-harvesting in Messa and Exo Mani, In: The Greek Salt - Proceedings of the $8^{\text {th }}$ Symposium of the Cultural and Technological Foundation of ETBA, 255-294, Cultural and Technological Foundation of ETBA, Athens (in Greek with English summary).

Sovinc A. (2005) Ecological characteristics of the Secovlje salinas. In ALAS (All About Salt) - Salt and salinas in the Mediterranean, Neves R., Petanidou T., Pinto S. and Rufino R. (eds.), 8185, Municipality of Figueira da Foz - ALAS, Lisbon.

Spilanis I. (2003) Tourisme et développment durable en Méditerranée - la Grèce. In Livre Blanc Tourisme et développment durable en Méditerranée. PNUE - PAM - Plan Bleu, http://www.planbleu.org/publications/tourisme.html (last access 25 July 2007).

Thibault M., Kayser Y., TamisierA., Sadoul N., CherainY., HafnerH., Johnson A. and Isenmann P. (1997) Compte-rendu ornithologique camarguais pour les années 1990-1994, Revue d'Ecologie - La Terre et la Vie, 52, 261-315.

Thompson I.B. (1999) The role of artisan technology and indigenous knowledge transfer in the survival of a classic cultural landscape: the salt-marsh of Guérande, Loire-Atlantique, France, Journal of Historical Geography, 25, 216-234.

Triantaphyllidis G.V., Poulopoulou K., Abatzopoulos T.J., Pinto-Pérez C.-A. and Sorgeloos P. (1995) International study on Artemia XLIX. Salinity effects on survival, maturity, growth, biometrics, reproductive and lifespan characteristics of a bisexual and a parthenogenetic population of Artemia, Hydrobiologia, 302, 215-227.

Valiente-Cánovas S., Ayarzagüena-Sanz M., Moncó-García C. and Carvajal D. (2002) Excavación arqueológica en las Salinas de Espartinas (Ciempozuelos) y prospecciones en su entorno, Archaia, 2, 33-45.

Velasquez C.R. (1992) Managing artificial saltpans as a waterbird habitat: species responses to water level manipulation, Colonial Waterbirds, 15, 43-55. 
Walmsley J.G. (2000) The ecological importance of Mediterranean Salinas, In: Saltworks: Preserving saline coastal ecosystems, Korovessis N. and Lekkas T.D. (eds.), 81-95, Global NEST - Hellenic Saltworks S.A., Athens.

Weller O. (2002) Aux origines de la production du sel en Europe - Vestiges, fonctions et enjeux archéologiques. In Archéologie du sel: techniques et sociétés. Internationale Archäologie, ASTK 3, Colloque 12.2, XIVe Congrès UISPP, Liège, Septembre 2001, Weller O. (ed.), 163175.

Zeno C. (2009) The ecological importance of the Margherita di Savoia Saltworks, Global NEST Journal, 11(1), 1-9. 